\title{
DEVELOPING A METHODOLOGY TO ASSESS THE ENVIRONMENTAL AND ECONOMIC PERFORMANCE INDEX BASED ON INTERNATIONAL RESEARCH TO RESOLVE THE ECONOMIC AND ENVIRONMENTAL PROBLEMS OF UKRAINE
}

\author{
Nadiia Shmygol' ${ }^{\text {, Olga Galtsova }}{ }^{2}$, Iryna Varlamova ${ }^{3}$
}

\begin{abstract}
The urgency of the research. Developing a new approach to economic and environmental problems grounded on the need to form new awareness and responsibility makes it necessary to conduct an in-depth study of the causes and nature of such problems at the current stage of the national economic development. The problem of developing and substantiating indices in countries such as the United Kingdom, Canada, the United States, is decided by special institutes. At the international level, numerous agencies, organizations, and committees such as WHO, UN, UNESCO, OECD, the World Bank, the European Commission, the Committee on Environmental Modelling (ISEM) are addressing this issue. For a comprehensive assessment of the sustainability of development, take into account the socio-economic and environmental indicators, as well as separate a group of institutional indicators. But for Ukraine, it is impossible to identify the links that require more attention and material support for raising the level of development both nationally and globally. Consequently, the method of calculating the index of sustainable development, taking into account the peculiarities of the functioning of the national economy, needs to be reconsidered and improved. Target setting. Both the state and the enterprises ignored the issues of environmental pollution, which gradually led to a threatening situation for the economy and the environment. Meanwhile, in the current context, economic and environmental problems remain unresolved and are increasingly deepening. Uninvestigated parts of general matters defining. Analysis of the resource potential revealed the urgent need to develop a clear and functioning mechanism of economic and environmental development, shaping the ecological awareness of the nation as a whole, managers and policy-makers, improving and transforming the existing regulatory framework and environmental legislation, as well as the corporate environmental management systems, in particular, based on the environmental performance index. The research objective. The goal of this article is to study the nature of economic and environmental problems of the industrial enterprises and to develop a model of the regional environmental and economic performance index aimed at reducing the environmental costs of the economic growth, ensuring the environmental sustainability of the region, and mitigating the harms in terms of public health. The statement of basic materials. There is evidence proving that the economic problems are mainly caused by the lack of attention to environmental issues. It is proved that to resolve the abovementioned problems, first, there is a need to develop the national economic and environmental awareness based on the national context, using international standards and introducing the best practices of international organizations. Conclusions. Thus, the strategic approach to ensure the sustainable socio-economic development of the country from the standpoint of the economic and environmental model is a transition from the implementation of separate measures to the development and implementation of an economic and environmental concept of the comprehensive public production rationalization.
\end{abstract}

Key words: economic and environmental problems, ecological regulation, environmental and economic performance index, economic and environmental awareness, mechanism of economic and environmental development.

JEL Classification: Q50, Q57, Q51, Q56

\footnotetext{
Corresponding author:

${ }^{1}$ Zaporizhzhia National University, Ukraine.

E-mail: nadezdash@ua.fm

ORCID: http://orcid.org/0000-0001-5932-658

${ }^{2}$ Classic Private University, Ukraine.

E-mail: olgagaltsova67@gmail.com

ORCID: http://orcid.org/0000-0003-0012-0371

${ }^{3}$ Zaporizhzhia National University, Ukraine.

E-mail: irina.varlamova.zp@gmail.com

ORCID: http://orcid.org/0000-0002-9921-3297
} 


\section{Introduction}

The world community is showing increasing interest in ways to achieve sustainable development of countries and regions, as well as protect the interests of the population. In this context, sustainable development is considered, on the one hand, in the context of changing the relationship between man and nature in order to expand the opportunities for economic growth, and on the other - as a coordinated global strategy for the survival of mankind.

Consequently, the current issue is the question of combining the ecological and economic and social components of development so that in the transition from generation to generation promoted safety and quality of life, the state of the environment, improved and society's needs were determined by the progressive social development.

During the crisis and especially in the post-crisis period, the issues of environmental pollution and its impact on the economic situation of the country are particularly important for Ukraine. A negative legacy of the previous economic system is negligence to the problem of environmental pollution, in particular, in the industrial regions where a lot of resources are concentrated. Both the state and the industrial enterprises that were under its strict control ignored the issues of environmental pollution, which gradually led to a threatening situation for the environment and the economy. Therefore, the problems, which had not been resolved in the past, gradually accumulated, deepened, and thus created a threat of economic and environmental crisis in Ukraine.

Most researchers and practitioners deemed it possible to resolve such problems by developing measures to eliminate the negative consequences caused by the activities of industrial enterprises. It was suggested to introduce fees for the use of natural resources and for environmental pollution. However, those fees were so small that it was much more cost-effective for companies to continue polluting the environment and pay fines. The second way to resolve such problems is to install pollution control and treatment facilities, which is very costly for enterprises and requires significant investments. As the domestic companies have a weak investment base, there is a need to attract foreign capital, but since foreign funds are provided at high-interest rates and only for short periods, it is not cost-effective to invest money in environmental measures and innovative technologies. All this leads to further deterioration of the economic and environmental situation in our country. In our opinion, one of the effective ways to improve the economic and environmental situation in Ukraine is to develop economic and environmental awareness - an eco-economic paradigm, which will help to resolve complex problems at the national, regional, and local levels, will allow to develop the algorithms to create an economic mechanism to achieve the resource potential, and to make complex decisions, harmoniously combining the rational use of natural resources with the concept of socio-economic development of the country. Developing a new approach to economic and environmental problems grounded on the need to form economic and environmental awareness and responsibility for decision-making, makes it necessary to conduct an in-depth study of the causes and nature of economic and environmental problems at the current stage of national economic development by introducing a new methodology to assess the environmental and economic performance index of the regions of Ukraine. Both the state and the industrial enterprises that were under its strict control ignored the issues of environmental pollution, which gradually led to a threatening situation for the economy and the environment. Therefore, the problems, which had not been resolved in the past, gradually accumulated, deepened, and thus created a threat of economic and environmental crisis in Ukraine.

\section{Actual scientific researches and issues analysis and the research objective}

Current realities reaffirm the urgency and the need for scientists and practitioners to study the nature of environmental problems and their impact on the economic situation both on an economic entity and on the country as a whole. This problem has been widely studied in many scientific publications of national and international scientists. It should be noted that the environmental aspects in the activities of industrial enterprises were studied by such scientists as $\mathrm{O}$. Amosha, O. Balatskyi, P. Barna, A. Zhulavskyi, Ye. Lapin, L. Melnik, Ye. Pozacheniuk, O. Syromiatnykova, V. Feshchenko, etc. (Barna, 2009; Melnyk, 2006; Pozacheniuk, 2008; Feshchenko, 2009; Syromiatnykova, 2008). The theoretic foundations to study the linkage between the economy and the environment and the problem of sustainable eco-economic development of the industrial enterprises has been laid by such scientists as B. Burkynskyi, T. Halushkin, L. Hranych, B. Danylyshyn, M. Dolishnii, T. Domina, V. Yevtushevskyi, Yu. Lysenko, A. Sadekov, and V. Shevchuk (Dolishniy, 2006; Domin, 2003; Lysenko, 2003; Shevchuk, Satalkin, Bilyavskyy, 2004). Publications of the following economists were aimed at solving the problems of improving the economic and environmental management of the enterprises: N. Bondarenko, O. Veklych, H. Hryhorian, V. Hrynova, M. Kyzym, V. Lukianykhina, A. Nyz, V. Ponomarenko, I. Semeniak, V. Trehobchuk, L. Ukrainska, V. Khesle, M. Khokhlov, and V.Shepa (Lukianykhina, 2002; Veklych, 2000). Research studies of the following foreign authors have been of great importance to attain the current level of the environmentally sustainable economy: R. Welford, G. Winter, A. Gouldson, K. Gofman, A. Gusev, T. Dyllick, 
Ye. Korotkov, G. Motkin, D. Ottman, N. Pakhomova, K. Peattie, M. Porter, I. Potravnyi, C. Richter, N. Reimers, P. Roberts, G. Serov, W. Hopfenbeck, S. Schmidheiny, etc. Meanwhile, economic and environmental problems remain unresolved and are increasingly deepening in the context of current activities of the national industrial enterprises.

Uninvestigated parts of general matters defining. Analysis of the resource potential revealed the urgent need to develop a clear and functioning mechanism of economic and environmental development, shaping the ecological awareness of the nation as a whole, managers and policy-makers, improving and transforming the existing regulatory framework and environmental legislation, as well as the corporate environmental management systems, in particular, based on the environmental performance index.

The goal of this article is to study the nature of economic and environmental problems of the industrial enterprises and to develop a model of the regional environmental and economic performance index aimed at reducing the environmental costs of the economic growth, ensuring the environmental sustainability of the region and mitigating the harms in terms of public health.

\section{Analysis of the indicators of national production ecologization}

One of the most important factors in ensuring the transition of a society to the sustainable development model is the increased economic and ecological efficiency of the economic activities at the regional level. Ukrainian economy faces the need to undergo deep restructuring and renewal to create conditions for the accelerated modernization of production processes and to ensure the competitiveness of the national products while reducing the negative environmental impacts. The economic policy can only be effective if the environment is preserved and should stipulate introduction of a conceptual framework for a strategy in the area of environmental management and protection, as well as its implementation to ensure sustainable economic, ecological, and social development of the region. The role of production ecologization can be revealed through the following functions: reproductive, spatial, and socio-ecological. The reproductive function is based on the possibility to create optimal conditions for preservation and reproduction of the environmental assets in order for the future generations to effectively use them. The spatial function is determined by the scientifically grounded system of eco-zoning, development of the territorial nature management patterns, and identification of the discrepancies within the eco-economic areas. It helps to optimize the location of production facilities and rationalize the environmental management and protection. The main goal of this function is to find a balance between human activities and nature. The socio-ecological function is related to environmental education, as well as good production practices.

It should be noted that the issue of making the national production more eco-friendly stems from the growth of technological environmental impact. According to the State Statistics Service of Ukraine, harmful emissions into the atmosphere increased in 2011-2014. Whereas in 2011 this indicator amounted to 4,373.6 thousand tons with a decreasing trend, in 2014 it grew up to 5,186.6 thousand tons (by 18.6 percentage points). Water pollution considerably decreased in 2014 as compared to 2011 - by $42.7 \%$ (Figure 1 ).

Thus, there is a paradox, when in spite of the production decline due to the economic recession negative impact on the environment is growing. In their turn, negative environmental trends lead to the need of additional financial expenditures or funding redistribution to support and improve the efficiency of the existing economic structure and develop a new structure based on the sustainable development concept.

Thus, we would like to analyse the dynamics of capital investments and current expenditures on environmental protection and rational use of the natural resources in Ukraine in 2011-2014 (Table 1).

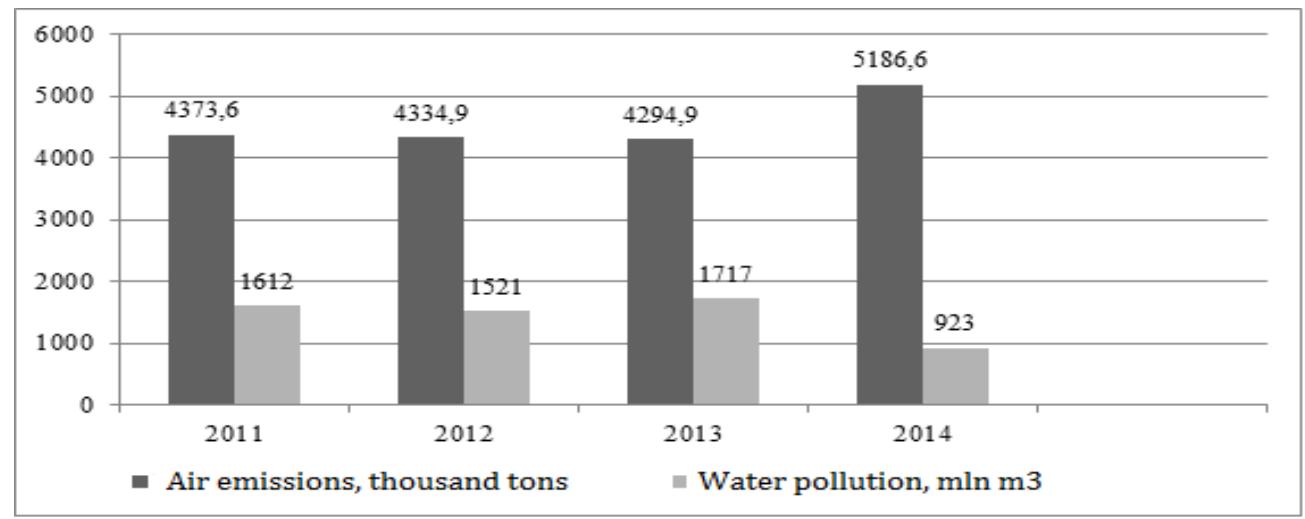

Figure 1. Dynamics in air emissions and water pollution in Ukraine 
Table 1

Dynamics of capital investments and current expenditures on environmental protection and rational use of the natural resources by environmental management activities, million UAH

\begin{tabular}{|l|c|c|c|c|c|c|c|}
\hline \multicolumn{1}{|c|}{$\begin{array}{c}\text { Environmental management } \\
\text { activities }\end{array}$} & 2011 & 2012 & $\begin{array}{c}\text { Rate of change in } \\
\text { 2012 as compared } \\
\text { to 2011,\% }\end{array}$ & 2013 & $\begin{array}{c}\text { Rate of change in } \\
\text { 2013 as compared } \\
\text { to 2012, \% }\end{array}$ & $\begin{array}{c}\text { 2014 } \\
\text { 2014 of change in } \\
\text { to 2013, \% }\end{array}$ \\
\hline $\begin{array}{l}\text { Capital investments and current } \\
\text { expenditures, total }\end{array}$ & $12,039.65$ & $6,589.3$ & $54.73 \%$ & $6,038.8$ & $91.65 \%$ & $7,959.9$ & $131.81 \%$ \\
\hline $\begin{array}{l}\text { Protection of the atmosphere and } \\
\text { climate change issues }\end{array}$ & $1,475.3$ & $2,462.7$ & $166.93 \%$ & $2,411.9$ & $97.94 \%$ & $1,915.1$ & $79.40 \%$ \\
\hline Wastewater treatment & $5,388.33$ & 846.9 & $15.72 \%$ & 834.1 & $98.49 \%$ & $1,222.2$ & $146.53 \%$ \\
\hline Waste management & $3,865.89$ & 730.5 & $18.90 \%$ & 713.9 & $97.73 \%$ & 784.0 & $109.82 \%$ \\
\hline $\begin{array}{l}\text { Environmental research (R\&D) } \\
\text { activities }\end{array}$ & 49.9 & 6.1 & $12.22 \%$ & 6.2 & $101.64 \%$ & 6.2 & $100.00 \%$ \\
\hline
\end{tabular}

Table 2

The volume of emissions per employee by types of economic activities, 2014

\begin{tabular}{|c|c|c|c|c|c|}
\hline \multirow[b]{2}{*}{ Economic activities } & \multicolumn{2}{|c|}{ Volume of emissions, thousand tons } & \multirow{2}{*}{$\begin{array}{c}\text { Number } \\
\text { of employees, } \\
\text { thousand people }\end{array}$} & \multicolumn{2}{|c|}{ Emissions per one employee, tons } \\
\hline & pollutants & carbon dioxide & & pollutants & carbon dioxide \\
\hline Agriculture, forestry and fisheries & 89.9 & 974.1 & $3,091.4$ & 0.09 & 0.32 \\
\hline Industrial production & $5,100.8$ & $261,064.2$ & $2,898.2$ & 0.02 & 90.08 \\
\hline $\begin{array}{l}\text { Transport, warehousing, postal } \\
\text { and courier services }\end{array}$ & 166.5 & $4,332.6$ & $1,113.4$ & 0.04 & 3.89 \\
\hline
\end{tabular}

The data presented in Table 1 clearly demonstrates that in 2014, the capital investment growth rate increased as compared to 2013 (31.8\%), while in 2011-2013 there was a decreasing trend in this indicator.

Investments in resolving the issues of atmosphere protection and climate change are going down. The level of investment in such areas of environmental activities as wastewater treatment and waste management is increasing.

Worryingly, the scope of capital investments in the rational use of natural resources, as well as in environmental research decreases every year (Figure 2).

To identify the types of economic activities, which are the major polluters, we will analyse some of them (Table 2).

The biggest pollutants in terms of pollutant emissions are agriculture, forestry, and fisheries (0.09 tons per employee), and the smallest - industrial producers (0.02 tons per employee). As for the carbon dioxide emissions, the indisputable leader is the industry (90.08 tons per employee), with agriculture accounting for the smallest amount of carbon dioxide emissions ( 0.32 tons per employee).

Analysis of the indicators of national production ecologization shows that the environmental situation remains challenging and poses significant threats in terms of human existence and activities. It is supported by the fact that in 2014 Ukraine ranked $95^{\text {th }}$ out of 178 countries in the international ranking based on the Environmental Performance Index calculated by the Yale University scientists using 25 indicators. In 2012 , it ranked $102^{\text {nd }}$ among 132 countries. Going up in the rating most likely occurred due to the increase in the number of countries analysed, with the least

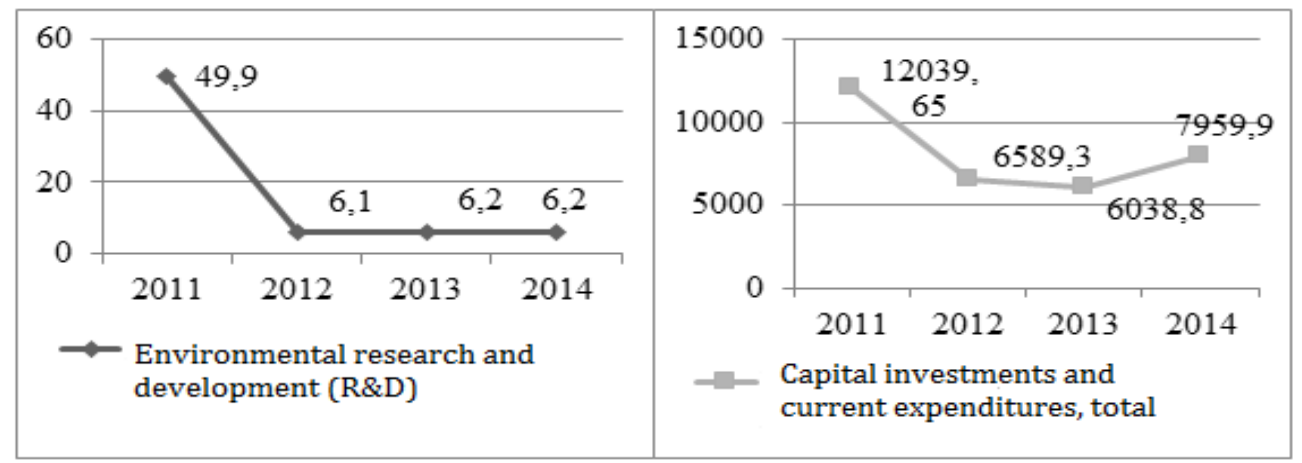

Figure 2. Dynamics of capital investments in environmental protection and rational use of natural resources, as well as environmental research 
developed African countries ranking lower in the rating.

Currently, there is a danger of deterioration of the environmental situation in Ukraine, which can be explained by the impact of economic, political, cultural, and other factors. It should be noted that the environmental situation can be stabilized by forming new values, revising the structure of people's needs, goals, priorities, and activities.

Experience of the countries with developed market economies confirms that strengthening market relations and competition involves a significant increase in the technical and technological level of the national production, enhancement of the resource and energy conservation, and structural transformation of the economy to reduce the environmental pollution.

In Ukraine, the situation is exacerbated by the fact that the economic reforms do not reflect all complexity of the economic processes, and in the context of crisis, the society is not aware of the new environmental problems. This confirms that resolving the issues of rational resource management, environmental protection and safety significantly influences the parameters of economic dynamics. Usually, when resolving environmental problems, the focus was on technical and technological aspects. However, at this stage, along with raising environmental requirements to the management and production technologies, ecological safety comes to the fore and becomes a decisive factor in the economy, determining its further effective development.

\section{Environmental problems}

Let us give a more detailed consideration to the environmental problems, which may be resolved using an integrated approach through the joint efforts of as many countries as possible. In recent years, the negative impact on the environment is growing and the number of global environmental problems is increasing. The environmental problems are not unified or isolated. These problems are relevant to all countries of the world and branches of production and have a significant impact on the economy both at the national and international levels. An indisputable proof of the linkage between the economy and the environment is the existence of a number of urgent problems to be resolved at all levels of the economy (Figure 3).

It should be noted that the economic problems are mainly caused by the lack of attention to the environmental issues. The main reason for careless attitude to the natural resources and their irrational use is the lack of economic and environmental awareness at the level of an individual, an enterprise, and at the country level. The impact of human activities ultimately leads to increased human involvement in the natural processes, which is accelerating and intensifying. That is why in recent years more and more referrals are made to issues related to the economic and environmental security both at the national and international levels. Current developments have caused the need to realize a significant number of problems related to the negative environmental impact, indicating the onset and start of the economic and environmental awareness formation. The most important environmental problems, which directly or indirectly affect the country's socioeconomic development, are: environmental pollution, ozone layer depletion, waste management, reduction in the number of species, demographic crisis, anthropogenic landscape changes, deforestation, irrational use of the natural resources, chemical and biological pollution, freshwater shortages, dangerous diseases, epidemics, etc. Unresolved environmental problems lead to negative consequences for both social (poverty, low level of human development) and economic (low competitiveness, labour productivity) development.

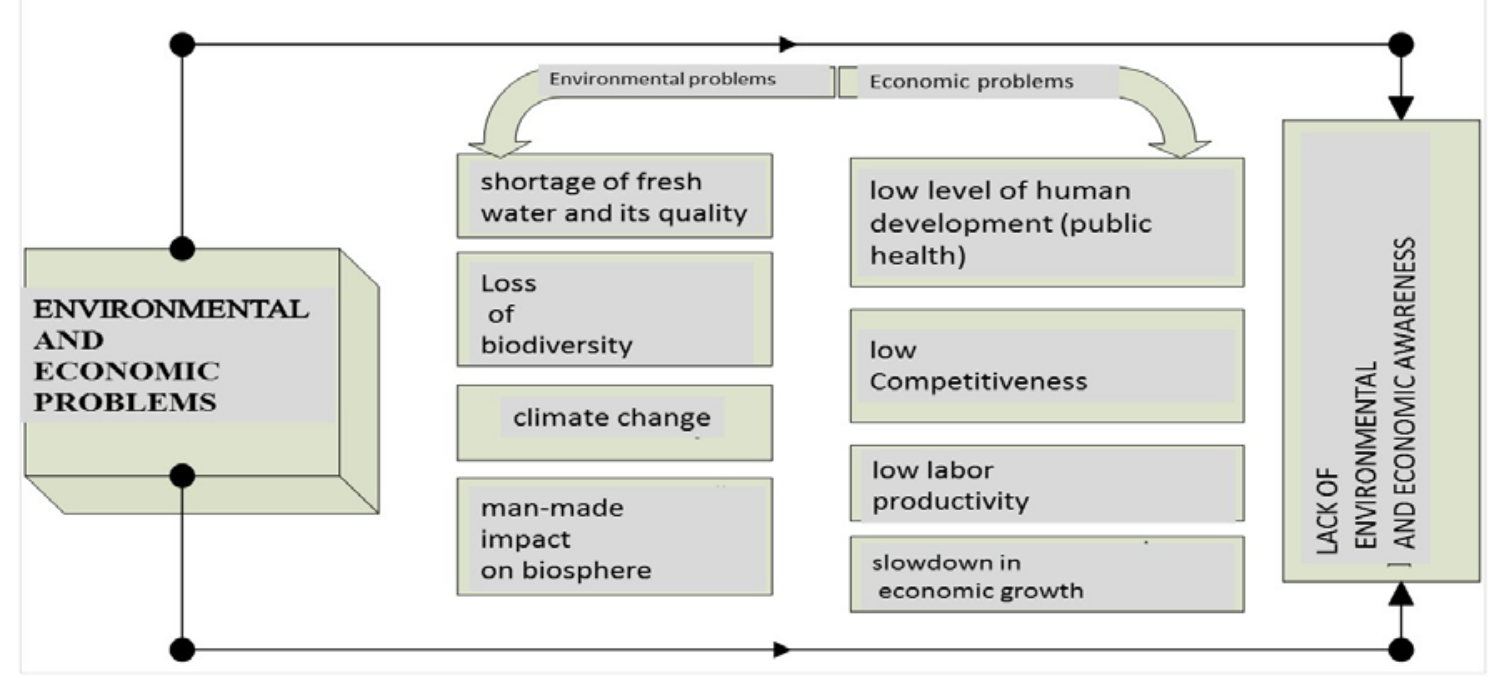

Figure 3. Economic and environmental problems 
First and foremost, solving this problem requires a reasonable and balanced policy to regulate and control the efficiency and rationality in using the national resources by limiting the anthropogenic impact, establishing monetary liability for violation of the sanitary regulations, and strict control over their implementation.

It should be noted that industrial enterprises are the main source of environmental pollution. The negative impact of industrial enterprises is revealed in the increased volume of harmful emissions into the atmosphere, determining the future trends of demographic and socio-economic development of the society. The increase of the negative environmental impact can be explained by the lack of economic and environmental awareness as a result of low responsibility at the micro- and macro-levels. One of the most popular methods to resolve the problem of environmental pollution by industrial enterprises is to increase fines. However, this method is inefficient and ineffective as the amount of such fines is so small that companies prefer to pay the fines rather than reduce the emissions, considering that their benefits significantly exceed the costs they incur.

Human needs are constantly growing, making it necessary to expand the scope of economic activities and to change the proportions of the world economy, production capacities, technologies, range of products, as well as industrial and personal consumption. Production and consumption models, which shaped in the world, no longer meet the requirements to ensure harmonious coexistence of humans and nature. The global environmental and closely related to it socioeconomic crisis which currently became a threat to the human existence was caused by two "explosions" population explosion, i.e. a sharp population increase in the last century together with the formation of the "consumerism" economy, on the one hand, and rapid industrial and energy development - on the other. Most scientists believe that it was the uncontrolled population growth, which was the main reason for the global environmental crisis, leading to other consequences. However, in our opinion, the reason of the unsatisfactory ecological and economic development level is the lack of understanding of the need for sound environmental management to ensure sustainability and stability for future generations; hence the decisive factor is not the amount of resources but the rationality and efficiency of their use. The complexity of the current economic processes makes it necessary to develop a sustainable development concept.

The global economic development agenda within the UN Millennium Declaration approved on 08.09.2009 (Resolution A/RES/52/2) stipulates that all countries are to ensure environmental sustainability in the context of anthropogenic impact. In line with this agenda, researchers from the Yale and Columbia
Universities together with the World Economic Forum developed an international Environmental Performance Index (EPI), which is openly published every two years since 2006. This index is based on two strategic goals: reducing environmental stresses on human health; promoting ecosystem vitality, and sound natural resource management.

\section{Using EPI: advantages and disadvantages}

Using EPI as a basic indicator characterizing the level of environmental security of Ukraine for comparison with other countries has both advantages and significant disadvantages when making management decisions at the level of the country and its regions.

The advantages of using EPI:

1. The index allows comparing the position of Ukraine with other countries of the world.

2. EPI components allow defining the strengths and weaknesses of Ukraine in terms of environmental protection and sustainability.

3. The EPI assessment methodology is publicly available and accessible, which allows assessing the impact of different management decisions on its value to a certain extent.

4. The level of expertise, the accuracy of inputs, and the lack of subjectivity when calculating EPI make it trustworthy.

On the other hand, practical use of the environmental performance index as an indicator of the national economy's development is associated with certain objective challenges, which significantly narrows the area of its application:

1. The methodology of EPI calculation has been constantly changing in 2006-2018. Every single report was different from the previous one in terms of the range of assessment indicators and the number of countries covered with the research. The most recent changes in the EPI assessment methodology took place in 2018 report: currently, it contains 24 indicators and is calculated for 180 countries of the world. Thus, constant changes in the calculation methodology and the number of countries covered and used as the comparison base do not allow using this indicator to analyse the dynamics of the indicator for a particular country.

2. Certain indicators included into EPI, such as the group of indicators "Biodiversity and habitat" may not be calculated based on the public data of the State Statistics Service of Ukraine. As for the researchers of the Yale and Columbia Universities, they receive the inputs from international agencies, world research institutions, and governmental bodies. The following methods are used for data collection: remote sensing; observations from the monitoring stations; surveys; academic studies; national industry reports; state statistics, etc. The indicators, which may not be received through continuous or sampling observations, are calculated based on the statistical 
models developed. That is why for the purposes of this study we can only use the calculated indicators with twoyear observation periods for our analysis. However, it is hardly possible to make similar calculations for regular monitoring of the situation.

3. The environmental performance index is calculated for every country as a whole. However, natural and climatic conditions of different regions of Ukraine, as well as their industrial and agricultural development, vary. Every region has its peculiarities in terms of economic capacity, social development, natural resources, and environmental pollution level. Therefore, it is not enough to assess EPI at the national level for the effective environmental management of Ukraine. There is a need to make such assessments for all regions of the country.

Thus, taking into account the abovementioned drawbacks, within this study, it is offered to develop an alternative methodology to assess the environmental and economic performance index for the regions of Ukraine. This index should cover three strategic goals as shown in Figure 4.

\section{Strategic goals}

Let us review each of the strategic goals in more detail:

1. Reducing the environmental costs of economic growth.

Any economic growth is associated with the increasing negative anthropogenic impact due to the growing environmental pollution. We may say that for the society, there are certain environmental costs it has to pay for every percent of the economic growth. The regions of Ukraine vary greatly in terms of their industrial structure. For example, the biggest air polluters in Dnipro and Donetsk regions are primary production, processing industry, and electric power supply, in Vinnytsia and Chernihiv regions - agriculture, forestry, and electric power supply, etc. Every industry has its average added-value standard and level of pollution.

The indicators of this group are relative performance indicators, which allow comparing the environmental harms and economic performance.
The harms are calculated in terms of the scope of air pollution, use and discharge of sewage waters, mineralization of sown areas, use of pesticides, accumulation of solid wastes, and deforestation. As for the economic performance, it is calculated as the gross regional product or the manufacture of agricultural and forestry products:

$$
i_{E P}=\frac{E H}{G R P},
$$

where $i_{E P}$ - environmental performance index of the economic growth; $E H$ - environmental harms; GRP gross (or industrial) regional product, c.u.

2. Ensuring environmental sustainability of the region.

Environmental sustainability of the region directly depends on the intensity of environmental harm caused. Calculation of the environmental harm intensity stipulates assessment of the rate of expansion, i.e. attribution of harms to the territory of the region. That is why the indicators of this group are based on the following formula:

$$
i_{E L}=\frac{E H}{R A} \text {, }
$$

where $i_{E L}$ - regional environmental load indicator; $R A$ - region area, ha.

3. Mitigating the harms in terms of public health in regions. Practical statistics widely uses relative indicators, which compare the harm caused and the population size. For example, air emissions per one person. However, in our opinion such indicators, which are based on the population size for comparison purposes, yield little information due to the following reasons:

- If the emissions on a certain territory remain on the same level, while the population grows, this indicator is reducing. However, the health of each individual will be influenced by the same scope of emissions.

- If the population of a territory with persistently high environmental load grows, it means that a higher percentage of people face negative manifestations of the anthropogenic impact.

That is why we would like to offer using a multiplicative model to calculate environmental harms in terms of public health:

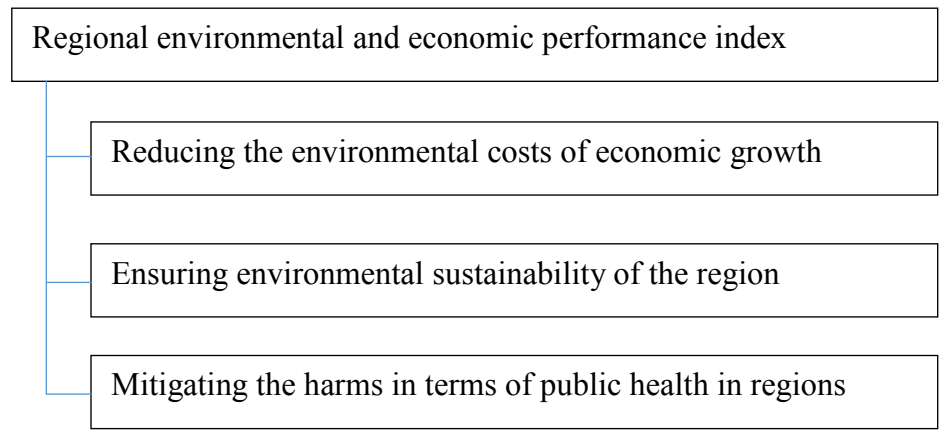

Figure 4. Functions of the regional environmental and economic performance index 


$$
i_{H}=E H_{N} \times P_{N} \text {, }
$$

where $i_{H}$-indicator of the environmental harm caused to human health; $E H_{N}$ - normalized environmental harm; $P_{N}-$ normalized population size.

Each of the factors presented in the model (3) varies in the range from 0 to 1 . Thus, the resulting indicator $i_{H}$ will also take values in the same range $[0 ; 1]$. Reducing the scope of environmental harms or reduction in the population size of the region will lead to the minimization of $E H_{N}$ and $P_{N}$ indicators. In turn, it will make the $i_{H}$ indicator approach zero. Vice versa, the increase of the normalized factors within the accepted values will automatically bring the $i_{H}$ indicator closer to 1 .

Normalization procedure is used to bring the indicator values to a consistent format using a formula:

$$
i_{\text {norm }}=\frac{i-i_{\text {worst }}}{i_{\text {best }}-i_{\text {worst }}},
$$

where $i_{\text {norm }}$ - the normalized value of the environmental and economic performance index; $i$ - entry value of the index; $i_{\text {best }}$ - the best possible value of the index which should be approached; $i_{\text {worst }}$ - the worst value of the index.

The $i_{\text {best }}$ and $i_{\text {worst }}$ values are selected based on the i values calculated for all regions. To allow monitoring of the resulting index dynamics, $i_{\text {best }}$ and $i_{\text {worst }}$ values were defined based on the 2014-2016 data. If the indicator was to be maximized, then $i_{\text {best }}$ was equal to the maximum value for all regions in recent years and $i_{\text {worst }}$ was equal to the minimum value. If the indicator was to be, vice versa, minimized, then $i_{\text {best }}$ was equal to the minimum value and $i_{\text {worst }}$ - to the maximum.

The above indicators are converted to the regional environmental and economic performance indicator (RI) using the additive and multiplicative model:

$$
R I=\alpha_{1} I_{E P}+\alpha_{2} E_{E L}+\alpha_{3} I_{H} \rightarrow \max ,
$$

where $I_{E P}, I_{E L}, I_{H}$ are, correspondingly, group indices for the first, second, and third strategic goal; $\alpha_{1}, \alpha_{2}$, $\alpha_{3}$ - weight coefficients to measure the weight of every strategic goal.

Weight coefficients $\alpha_{1}, \alpha_{2}, \alpha_{3}$ may take values from 0 to 1 , with their sum equal to 1 . In the regional index, every strategic goal should have equal impact on the $R I$. It is possible provided that the mean square deviations of each component should be equal to one another, i.e.

$$
\sigma\left(\alpha_{1} I_{E P}\right)=\sigma\left(\alpha_{2} I_{E L}\right)=\sigma\left(\alpha_{3} I_{H}\right) \text {. }
$$

To ensure the above equation, it is sufficient to resolve the following optimization problem in relation to the unknown weight coefficients $\alpha_{1}, \alpha_{2}$ and $\alpha_{3}$, using numerical methods:

$$
\begin{aligned}
& {\left[\sigma\left(\alpha_{1} I_{E P}\right)-\sigma\left(\alpha_{2} I_{E L}\right)\right]^{2}+\left[\sigma\left(\alpha_{2} I_{E L}\right)-\sigma\left(\alpha_{3} I_{H}\right)\right]^{2} \rightarrow \min (T F),(6)} \\
& \quad \alpha_{1}+\alpha_{2}+\alpha_{3}=1 ; \\
& \quad \alpha_{1} \leq 1, \alpha_{2} \leq 1, \alpha_{3} \leq 1 ; \\
& \quad \alpha_{1} \geq 0, \alpha_{2} \geq 0, \alpha_{3} \geq 0 .
\end{aligned}
$$

Group indices for each strategic goal were calculated based on the corresponding normalized values of the indicators using the following formulas:

$$
\begin{aligned}
I_{E P} & =\frac{\sum_{k=1}^{n_{1}} i_{E P, n o r m, k}}{n_{1}} ; \quad I_{E L}=\frac{\sum_{k=1}^{n_{2}} i_{E L, n o r m, k}}{n_{2}} ; \\
I_{H} & =\frac{\sum_{k=1}^{n_{3}} i_{H, n o r m, k}}{n_{3}}
\end{aligned}
$$

where $n_{1}, n_{2}, n_{3}$ is the number of indicators for the first, second, and third strategic goal, respectively.

The formulas (7) stipulated using the indicators with equal weight coefficients. If the expert decision-making has different preference patterns, such formulas take an additive and multiplicative format.

\section{Conclusions}

The issue of environmental management efficiency, overcoming the environmental crisis and improving the relations between industrial production and nature requires resolving environmental contradictions in the current environmentalmanagement. Focus exclusivelyon technical and economic growth with no linkage to the environment led to depletion, exhaustion, and the degradation of natural resources, environmental deterioration and negative social consequences. Thus, the strategic approach to ensure sustainable socio-economic development of the country from the standpoint of the economic and environmental model of the natural resource management reform implies transition from implementation of separate measures aimed at the resource conservation to the development and implementation of an economic and environmental concept of the comprehensive public production rationalization and ensuring its sustainable operation. To consider environmental factors and criteria, norms, and restrictions, it is necessary to establish effective control over the environmental conditions, as well as functional leverages to regulate environmental and economic relations.

We developed a model of the regional environmental and economic performance index aimed at reducing the environmental costs of the economic growth, ensuring the environmental sustainability of the region, and mitigating the harms in terms of public health. This index takes into account drawbacks of the practical application of the international index - EPI: it is fully based on the official data of the State Statistics Service of Ukraine, which are publicly available; allows monitoring such developments in dynamics and by regions.

Besides, it is worth mentioning that the problem of interaction between the environment and the economy may not be resolved without the formation of economic and environmental awareness, taking into account the national context, to raise the level of both individual and collective responsibility for the consequences of irresponsible actions in the future. 


\section{References:}

Barna, P. V. (2009). Vyznachennia neobkhidnosti provedennia ekonomiko-ekolohichnoyi restrukturyzatsiyi promyslovykh pidpryiemstv Ukrayiny [Determination of the need for economic and ecological restructuring of industrial enterprises of Ukraine]. Aktualni problemy ekonomiky, 3(93), 138-142.

Melnyk, L. H. (2006). Ekolohichna ekonomika [Environmental Economics], Sumy, Ukraine.

Pozacheniuk, E. A. (2008). Noosfernoe razvitie: sovremennye tendentsii [Noospheric development: current trends]. Ekolohichnyy visnyk, 3, 6-10.

Feshchenko, V. P. (2009). Upravlinnia pryrodokorystuvannyim promyslovykh pidpryiemstv na pryntsypakh staloho rozvytku [Environmental Management of industrial enterprises on the principles of sustainable development], Kyiv, Ukraine.

Syromiatnykova, O. (2008). Ekolohycheskiy menedzhment - element intehrirovannoy sistemy upravleniia predpriiatiem [Environmental management - element of the integrated system of enterprise management]. Problemy teorii i praktiki upravleniia, 4, 86-95.

Dolishniy, M. I. (2006). Rehionalna polityka na rubezhi XX-XXI stolit : novi priorytety [Regional policy at the turn of XX-XXI hundred-pouring: new priorities], Kyiv, Ukraine.

Domin, O. (2003). Polityka rehionalnoho rozvytku v umovakh pohlyblennia rynkovykh reform v Ukrayini [Policy of regional development in the context of lublinie market reforms in Ukraine], Ekonomika Ukrayiny, 6, 4-13.

Lysenko, Yu. (2003). Ekolohycheskiy podkhod k upravleniu predpriiatiem: problemy i perspektivy [Ecological approach to the management of the enterprise: problems and prospects]. Ekonomika Ukrainy, 5, 33-40.

Shevchuk, V. Ya., Satalkin, Yu. M., Bilyavskyy, H. O. (2004). Ekolohichne upravlinnia [Environmental management], Kyiv, Ukraine.

Lukianykhina, V. O. (2002). Ekolohichnyy menedzhment u systemi upravlinnia zbalansovanym rozvytkom [Environmental management in the management system of the balanced development], Sumy, Ukraine.

Veklych, O. O. (2000). Formuvannia ekonomichnoho mekhanizmu staloho rozvytku Ukrayiny [Formation of the economic mechanism of sustainable development of Ukraine]. Visnyk NAU, 2, 3-16.

Welford, R. (1993). Environmental Management and Business Strategy, London, United Kingdom.

Hofman, K. H. (1998). Ekonomika pryrodopolzovania (iz nauchnoho naslediia) [Environmental Economics (from scientific heritage)], Moskow, Russian Federation.

Husev, A. A. (1998). Ekonomycheskaia otsenka prirodnykh resursov v sisteme mer po osushchestvleniiu pryrodno-resursnoy politiki hosudarstva [Economic evaluation of natural resources in the system of measures for the implementation of natural resource policy of the state], Ekonomyka pryrodopolzovanyya, 4.

Motkyn, H. A. (1997). Strakhovanie riska zahriazneniia okruzhaiushchey sredy i eho metodolohycheskie osobennosti [Insurance risk of environmental pollution and its methodological features]. Sumskyy Hosudarstvennyy tekhnycheskyy unyversytet.

Reimers, N. F. (1992). Nadezhdy na vyzhyvanie chelovechestva, kontseptualnaia ekolohiia [Hopes for the survival of humanity, conceptual ecology], Ekolohyya.

The state statistics service of Ukraine. Emissions of pollutants and greenhouse gases into the atmospheric air from stationary sources of pollution. Retrieved from: http://ukrstat.gov.ua/ 